\title{
Internet as a Tool to Promote Women's Entrepreneurship. Selected Aspects
}

\author{
Paulina Siemieniak*, Małgorzata Rembiasz**, Jakub Pawlak ${ }^{* * *}$
}

The Internet is an important tool in the context of activity of women-entrepreneurs due to the possibility of flexible work organization, hence it facilitates the reconciliation of the parental role with professional activity. Therefore, it is advisable to study the awareness, the level of use and limitations on the use of various kinds of virtual tools and applications. This article is of a review and conceptual nature but also relies on the results of previous studies conducted by the authors.

Keywords: women entrepreneurs, professional activity of women, Internet.

Submitted: 10.09.16 | Accepted: 24.10.16

\section{Internet jako narzędzie wspierania przedsiębiorczości kobiet. Wybrane problemy}

Internet stanowi obecnie nie tylko popularne, ale wręcz niezbędne narzędzie prowadzenia dziatalności gospodarczej. Obrazuje to fakt, że firmy aktywne w Internecie tworza więcej miejsc pracy, w porównaniu z przedsiębiorstwami, które jeszcze nie weszly do sieci. Celem niniejszego artykutu jest dokonanie przegladu możliwości, jakie daje Internet właścicielom mikro, matych $i$ średnich przedsiębiorstw. W ostatnim czasie widoczne sq zmiany $w$ sposobie korzystania z Internetu, który staje się powszechnym kanatem wymiany dóbr i ustug. Aktywne uczestnictwo $w$ sieci umożliwia zarówno sprawna obstuge finansowa przedsięwzięcia o charakterze rozwojowym, jak również pozyskiwanie niezbędnych informacji, zawieranie kontaktów czy poszukiwanie pracowników.

Autorzy starali się przede wszystkim przedstawić znaczenie tego narzędzia w kontekście wspierania przedsiębiorczości kobiet. Internet stanowi ważne narzędzie w kontekście aktywności kobiet - przedsiębiorców ze względu na możliwość elastycznej organizacji pracy, ułatwiajacej godzenie roli rodzicielskiej z działalnościa zawodowa. Stąd też celowe jest badanie świadomości, poziomu wykorzystania i ograniczeń $w$ użytkowaniu różnego rodzaju narzędzi $i$ aplikacji internetowych.

Słowa kluczowe: kobiety przedsiębiorcy, aktywność zawodowa kobiet, Internet.

\footnotetext{
* Paulina Siemieniak, PhD - Faculty of Engineering Management, Poznan University of Technology. Correspondence address: Faculty of Engineering Management, Poznan University of Technology, 11 Strzelecka Street, 60-965 Poznan; e-mail: paulina.siemieniak@put.poznan.pl.

*** Matgorzata Rembiasz, PhD - Faculty of Engineering Management, Poznan University of Technology. Correspondence address: Faculty of Engineering Management, Poznan University of Technology, 11 Strzelecka Street, 60-965 Poznan; e-mail: malgorzata.rembiasz@put.poznan.pl.

*** Jakub Pawlak, PhD - Faculty of Engineering Management, Poznan University of Technology. Correspondence address: Faculty of Engineering Management, Poznan University of Technology, 11 Strzelecka Street, 60-965 Poznan; e-mail: jakub.pawlak@put.poznan.pl.
} 
JEL: L26, L53, M31

\section{Introduction}

In recent years, the owners of SMEs from various industries have learned that the Internet is not only a popular but also necessary tool for conducting business. Currently, it can be used in all areas of business activities. Using it is not limited by time or geography and other advantages include even the low cost, unlimited access and interactivity. The Internet is an innovative form of communication that allows the use of information necessary for the production and distribution of new goods and services. Currently, it has become a strategic challenge to any business. No company can afford to ignore the competition in the field of e-business.

The aim of this article is to make a multifaceted review of the opportunities offered by the Internet to female entrepreneurs. The authors try to show the importance of this tool in the context of the promotion of women entrepreneurship as an underrepresented group among Polish business owners. According to research results, it is estimated that companies run by women, both in Poland and in the vast majority of European countries, account for about $30 \%$ of all companies. However, studies show that women have a considerable potential in terms of entrepreneurship, such as a high level of education and professional experience. Moreover, conducting business allows many women to organize their working time in a flexible manner, which makes it easier to perform parental duties.

\section{Women as Entrepreneurs}

The importance of women's entrepreneurship is growing in contemporary society. Nevertheless, many studies indicate the presence of numerous restrictions on women's entrepreneurship. The analysis of the suitability of various forms of business support for female entrepreneurs as women setting up their business thus becomes an important problem (Siemieniak, 2015).

When analyzing the entrepreneurial activity of women in the European Union, it is clear that women - just like in the world
- are on average the owners of every third company. The studies also revealed lower activity rates for women, who take part-time work and earn lower wages, seen as a result of societal expectations of women mostly related to their main responsibility for childcare and other family members. You can therefore say that in spite of the changing socio-cultural norms, there is still a common belief that entrepreneurship is a domain of men. The possibilities of increased activity of women should therefore be sought to stimulate entrepreneurship among women, especially mature, qualified college graduates and those returning from maternity leave (see Siemieniak and Luczka, 2016).

An interesting fact is that there is a big difference between the numbers of men and women engaged at an early phase of a enterprises' activities in Poland, that is from the establishment of a company up to the 42nd month of its existence: only $13.1 \%$ of men and $5.1 \%$ of women are involved in initiating and conducting new business (Zabierowski et al., 2012).

According to T. Łuczka, one can distinguish the following features characterizing enterprises run by women:

- they are of smaller size,

- they have less capital,

- they prefer owner's equity for financing their activities,

- they usually operate in branches associated with smaller gains, such as retail trade and services,

- they are rarely high-tech companies,

- they are less focused on the success than companies led by men,

- they put their focus first on a larger number of customers and later on achieving profit,

- women undertake economic activities later than men,

- owners exhibit insufficient knowledge in the area of leadership and management (Luczka, 2013).

It was observed all over the world that companies run by women and men differ in the type of undertaken economic activity: especially very few businesses run by women occur in industries such as information technology, manufacturing, con- 
struction and transport (Robb, Coleman and Stangler, 2014, p. 5). Women lead smaller and younger companies reaching lower turnover. Furthermore, they assume a smaller growth of their companies. These are mostly service companies, rarely innovative ones of a larger - supra-regional range on the market, mainly in the traditional sectors of the economy (Arum and Müller, 2004, p. 448, as cited in: Leicht and Lauxen-Ulbrich, 2005).

Entrepreneurship is a complex process conditioned by a wide variety of factors. Founding a company, achieving its strong competitive position or just even "only" surviving on the market depends on both the presage factors of the entrepreneur herself and the external conditions in which she operates. According to the research results of the Polish Agency for Enterprise Development, the most common barriers to business growth - for both women and men in Poland - are too high non-wage labor costs, problems with attracting new customers, complicated financial procedures, time-consuming formalities relating to, among others, issuance of permits or licenses, as well as changing labor law. A significant difference in business barriers between men and women concerns the conditions of family life and caring responsibilities towards small children. Women are more likely than men to indicate limited access to institutional childcare (PARP).

It can be concluded that the lower orientation of women on the growth of their businesses may be conditioned by factors resulting from having a family. Female entrepreneurship in Poland is primarily affected by the following conditions (Balcerzak-Paradowska et al., 2011, p. 10):

- the children's age,

- form of childcare (access to care in nurseries, scope of care in the nursery),

- family model,

- the ability to organize professional and family activities,

- the nature of the activities (industry) carried out by women (work at home vs. business trips),

- lack of the same employee rights as for contract employees: maternity, parental leave.

One factor limiting the growth of the company is therefore striving to balance the demands of work and family life. A special group of moms running their own com- panies are those that make up single-parent families. This family type accounts for about $25 \%$ in Poland. Due to the economic development of the country and the future of children raised in such families, their main source of income definitely should not be all kinds of allowances and social welfare. It is much more convenient to create a legal and institutional framework to support this group of women in running their own business (Rembiasz, 2016).

As estimated by A. Robb, S. Coleman and D. Stangler, there are less than $10 \%$ of companies run by women among fast-growing companies. The reason for this is seen in lower financing: the owners are more dependent on their own resources than on external sources of financing, which has a negative impact on their business: fast growing companies require a greater financial outlay (Robb, Coleman and Stangler, 2014). Therefore, access to financing can be - next to psycho-social factors, educational attainment and lower risk appetite - also an important reason for a smaller number of companies focused on growth that are led by women.

The presence of these barriers implies the need for supporting actions so as to exploit the combined potential of a flexible form of work and self-employment. This perspective allows the activation of women and thus economic growth of regions and countries.

\section{Impact of the Development of the Internet on Businesses and Their Environment}

According to the CBOS study, $64 \%$ of adult Poles use the Internet on a regular basis ${ }^{1}$ (Internet World Stats. Usage and Population Statistics..., 2015). In recent years, the number of Internet users has grown rapidly. It is estimated that ten years ago, Internet users accounted for only one-quarter of adults, while in 2010 more than half of those surveyed used this medium at least once a week (Komunikat $z$ badań CBOS..., 2015). $73.5 \%$ of the European population are Internet users (Internet World Stats. Usage and Population Statistics..., 2015).

From the perspective of supporting women's entrepreneurship, it is appropriate to look at the trends and habits of using the network. This is important for both current and potential owners in the SME sec- 
tor, as well as consumers of their products or services.

The universality of the use of the Internet in Poland differs from one age group to another (Komunikat $z$ badań CBOS..., 2015). Among adults at the age of 18-34, over $95 \%$ are Internet users; $86 \%$ in the 35-44 group. The smallest group among Internet users are the elderly (over 65 years), and - which often goes hand in hand - those with primary education (in both cases less than 18\%). Besides those, all the others are online. Internet users account for $86 \%$ among the self-employed. Even in the group of farmers and unskilled workers, more than half declare the use of the Internet. Network users usually live in large cities. More than three-quarters live in cities with over 100,000 residents. Internet users account for more than half of inhabitants of small towns and villages. On average, we spend 13 hours a week on the network, and men are online slightly more often per week than women (14.38 and 11.66 hours respectively) (ibid.).

The growing popularity of the Internet is currently mainly affected by being used to exchanging goods and services. More than half of those surveyed by the CBOS declare to have bought something using the network, and almost one fourth - to have sold something. This trend has been increasing compared to the previous year. We also increasingly make regular online purchases ( $29 \%$ of all adults). $44 \%$ of all adults and $69 \%$ among Internet users use electronic banking. Only few respondents pay the network for access to content, e.g. newspapers, websites, video materials. In this respect, the Internet users with higher education and higher incomes, accounting for about $20 \%$, stand out positively. Recently, more than half of the respondents have read newspapers online and more than a third of them have looked through blogs. Every third Internet user declares that they have posted messages on online forums or social networks in the last month. Interestingly, corresponding via instant messengers or forums shows no correlation with the gender of respondents and women are only slightly more likely to talk through instant messaging than men. Two-thirds of Internet users are present on social networks; more than $80 \%$ use them regularly. More often they are women (three-quarters of Internet users) and young people less than
34 years old. Social networking sites are rarely used to establish new contacts, but rather to maintain and renew relations. These last two behaviors are exhibited slightly more often by women than men. The representatives of the female sex more often post content on social networks. The use of social networks for networking and business is mainly popular among entrepreneurs and more frequent among male than female Internet users. One-fifth of Internet users look for work in this way (Komunikat $z$ badań CBOS..., 2015).

Research on enterprises of the Polish SME sector carried out in 2015 shows that the vast majority of entrepreneurs $(80 \%)$ declare that the Internet could help grow their business (DELab..., 2015). In addition, the same study shows that $70 \%$ of business owners see the benefits of expanding competencies of their staff in the use of the Internet. The level of adoption of digital technologies by small and medium-sized enterprises in Poland is low compared to other EU countries (Kompetencje cyfrowe polskich matych $i$ średnich przedsiębiorstw...). This is because Polish SMEs face difficulties recruiting employees with the right competencies and thus do not implement new technologies that require skilful handling.

Global research expands the list of advantages of the new medium. According to a study of 2007, main benefits of the use of the Internet by Canadian companies include: better activities coordination with suppliers, customers and partners, as well as access to new customers. The perception of benefits resulting from using the Internet by the Korean companies (in 2009) is described by a reduction in transactional costs, access to new clients, time savings/ faster business processes (OECD Internet Economy Outlook..., 2012, p. 151).

It is noteworthy that Polish companies being active on the Internet create twice as many jobs compared with companies that are not yet part of the network (Kaczor, 2015). The use of the Internet depends on the industry and the product: the Internet is least frequently used in the public, educational and non-profit sectors (Thaler and Kos-Łabędowicz, 2014). Commercial use of the Internet involves: the exchange of information (email, videoconferences, instant messaging, EDI systems), use of the WWW and creation of the company's 
own websites (Thaler and Kos-Łabędowicz, 2014).

Using the Internet influences many business areas. Therefore, it amends the approach to the strategic analysis of companies, including Porter's Five Forces Analysis (Talar and Kos-Łabędowicz, 2014). The Internet helps to reduce entry barriers and to start a new business. The establishment of an online store requires, for example, less financial resources than the traditional point of sale. Moreover, the Internet not only shortens the product life cycle but also promotes innovative solutions in the field of customer service. It also allows the bargaining power of customers to be increased by facilitating access to information about products or services. The ability to compare them affects the company's marketing activities. The Internet also influences the bargaining power of suppliers, who, thanks to easy access to information, can educate themselves on the situation in their industry. The last factor mentioned in the Porter model - threat from existing competitors - is also shaped by the ease of finding information on the Internet. Businesses can thus compare their competitors' products and services, which contributes to the quality and shapes their honesty.

\section{Possibilities of Using the Internet in SMEs in the Context of Women's Entrepreneurship}

More than a decade ago, researchers of the phenomenon of entrepreneurship Chodak and Ropuszyńska-Surma - distinguished the following groups of possibilities in using the Internet in SMEs (2004):

- downloading information from websites,

- downloading collections and programs from the Internet,

- facilitating and expanding contacts,

- promotion of the company,

- shortening the logistic chain,

- facilitating the flow of money,

- facilitating contacts with authorities. The authors identified as well factors limiting the use of the Internet by the Polish SME sector (ibid.):

- psychological - attitude of SME employees, business partners and customers (e.g. aversion to financial settlements via the Internet), business owners' habits (e.g. habits affecting inventories),
- economic and legal (e.g. price of Internet connection, VAT on Internet services),

- technical (e.g. the level of development of telecommunications structures, scale of utilization of wireless connections).

In turn, the increased use of the Internet by SMEs, according Chodak and Ropuszyńska- Surma, favors:

- education,

- cost reduction of Internet usage,

- development of competition in the telecommunications sector,

- development of technical infrastructure and increased use of wireless technologies.

At present, after more than a decade since the formulation of the above conclusions, in connection with the rapid development of the Internet, it should be noted that factors promoting the use of the Internet by businesses have been strengthened.

It should be emphasized that women running their own companies are not a homogenous group and their activities afford the usage of various Internet tools. Some women need flexible work organization due to the parental function. So one can distinguished mompreneurs - mothers of young children running their own online business. From the economic development point of view, it is worth supporting this group of entrepreneurs. According to a survey conducted by MultiBank in 2011, every third company using the services of this bank was operated by a woman. However, only onethird of them were run by a mother and the smallest percentage of women among them were those less than 34 years old. These data show how difficult it is for young mothers raising children to reconcile work with family life (Wojciechowska, 2012).

Another group of entrepreneurs in need of special attention are mature women who do not belong to the group of $55+$ entrepreneurs. They need other forms of support than young mothers, they use the Internet in another way in their companies and often operate in traditional sectors. It is worth mentioning that the development of a mature business results from today's process of demographic aging. When their children are grown up and do not require any care, many mature women want to fully participate in their countries' economic and social life. Age can be a kind of advantage here, because mature people are generally 
perceived as more reliable and trustworthy, which fosters lasting business contacts (Rembiasz, 2014). The use of suitable Internet tools can undoubtedly promote the development of women's businesses at a mature age. Research shows that older entrepreneurs do not need funds for the development of their companies, because they do not plan it at all. They consider training in communication with the use of modern technology as more helpful (Wasilczuk, 2014).

One should also consider the role of the Internet in supporting women's entrepreneurship in the context of the tendency to undertake 'community actions', which seems to be characteristic and a factor supporting female entrepreneurship. An example is the current development of social entrepreneurship whose goal is to offer innovative solutions to help increase public integration. Social entrepreneurs identify and employ people excluded from economic activity who do not have sufficient financial resources or instruction to find a job or achieve a decent standard of living (Martin and Osberg, 2007). One can recall multiannual American studies according to which women are most likely to engage in the social economy, where they achieve the greatest influence (Fisher, 2003).

According to the authors of this article, the question to be asked is how virtual tools are used by active business women for entrepreneurial activities for the following purposes:

- search for information on entrepreneurship and available ways of support,

- identification of appropriate traditional and innovative forms of business financing,

- use of training opportunities through eLearning,

- acquisition of associates,

- networking,

- developing promotional activities,

- implementation of the sales process through the Internet,

- maintaining and building long-term relationships with existing and potential customers,

- creating the image to the external business environment.

Measures to achieve most of the objectives stated above are described later in this article.

\section{Internet as a Distribution Channel}

According to the eCommerce Report 2015, more than half (55\%) of Internet users make purchases over the Internet. They describe online shopping as a convenient, cheaper way of purchasing goods allowing a wider choice. Additionally, they buy more frequently in Polish e-shops. Apart from making purchases online, they search for information about products they intend to buy $(65 \%)$ and compare prices (63\%) (Raport e-commerce Polska 2015).

Online sales are one of the forms of the Internet use by enterprises. Chodak mentions that the use of the Internet as an additional distribution channel can be analyzed in relation to retailers (Chodak, 2010). According to him, the advantages of using the Internet to distribute goods are:

- the ability to reach a wider group of customers,

- sale of unused warehouse stocks for which local demand no longer exists,

- reducing storage costs,

- lower labor costs as customers per form the sales activities on their own,

- reducing marketing costs by informing about another channel of distribution (e.g. the information on the web about traditional sales),

- the ability to better present the offer,

- the ability to view the goods in conditions comfortable for the customer,

- quick search of the desired product,

- the ability to get to know other consumers' opinions.

Given the growth rate of online sales, it can be expected that more and more businesses (including companies led by women who seek flexible forms of work) will use this channel of distribution. It can bring benefits both to companies operating exclusively online and to those that treat it as enrichment of traditional sales.

At the same time, it should be remembered that, as emphasized by Dange and Kumar, purchasing decisions are based largely on the degree of confidence in the product or service as well as in their sellers, both in-store and online. Their research results show that the level of confidence in Internet sales is lower compared to that which occurs in the face-to-face contact in a brick and mortar shop. The e-commerce credibility increases when there are web- 
sites providing information about customer service, location, contact data and when the customer is convinced that the entrepreneur really exists (Kumar and Dange, 2012).

\section{Internet as a Source of Information on Running Business}

The Internet has become the primary medium to communicate with the external environment in Polish companies. It is also seen by dealers as a primary source of information. SMEs prefer to buy and use four types of information in strategic management (Strategiczne źródta informacji $w$ działalności przedsiębiorstw... PARP, 2010):

- information about new products and technologies,

- information on the economic situation,

- information on new customers,

- information about changes in the law.

An important source of information for SMEs are external institutions, including the public ones. The key channel for obtaining information is - next to telephone and personal contacts - the analysis of the websites of institutions. An underutilized channel is email, which is preferred by entrepreneurs for several reasons (speed of contact, low costs, ease of archiving) (ibid.). As follows from the PARP analysis, from the perspective of small and mediumsized enterprises, it would be desirable to create a channel of information integrating very scattered information in the form of an Internet portal (e.g. about the characteristics of social networks). Furthermore, it would be appropriate to publish important business data and documents on such websites (ibid., p. 12).

The information that entrepreneurs, including women-entrepreneurs, can find on the net using portals for small and medium-sized enterprises relates to financing, technology, law, principles of the operation of the EU market, and organizations and institutions providing support for SMEs. Some of them also make it possible to establish cooperation, to find an investor, sell real estate, etc. An important role in this context is played by portals for women in business, stressing the importance of social support (e.g. in the form of mentoring), transferring contacts between Internet users to real life ${ }^{2}$.
According to research results, industry portals and specialized websites belong to the most appreciated sources of information among business owners, supporting them in running their companies (Siemieniak and Łuczka, 2016). They are considered at a similar level to the clues and hints delivered by close friends. At the same time, female entrepreneurs only rarely use the websites of key institutions supporting economic activity, such as PARP and the Ministry of Regional Development (ibid.).

A particular source of knowledge is provided by web forums that allow interactive communication of those involved in setting up or running their own business. In Poland, there are institutions uniting entrepreneurial women of all ages, with different family situations, education and income. Each of these organizations has a website containing the information needed to conduct business and to exchange information. For example, the Foundation "Center for the Advancement of Women" offers a variety of training and consulting services and is also a partner for projects that support women in terms of equality in socio-economic life (http://www. promocjakobiet.pl). In turn, the MaMa Foundation supports entrepreneurship of mothers, initiating projects to help women return to social and professional life after childbirth (http://fundacjamama.pl). In addition, initiatives interesting from the point of view of the use of the Internet in business include the project "Mother Tech Lab. Design your balanced career path". It involves workshops that are aimed at promoting entrepreneurship among mothers of children under the age of three and at presenting them with the opportunity to use modern technology in conducting their own projects (http://miastomamy.wix.com/ fundacjag10\#! aktualnoci/c11hh).

\section{Company Websites}

The benefits of using the Internet primarily include access to its wealthy archive of information. Businesses can use it in several ways. Companies use the web to promote their services and products, provide information related to their offer and the nature of the business or to the organization of the sales process. The website is the most reliable and direct source of information about the enterprise. 
According to the 2015 research by Millward Brown, already $70 \%$ of companies have their websites, with $20 \%$ of them offering mobile versions (Sledziewska and Włoch, 2015). The same studies show that Polish entrepreneurs rarely sell their products and services on the Internet - only one in five firms sells through the Internet.

A popular form of websites are corporate blogs. These are passive communication tools, which means that the users themselves need to look at the website to familiarize themselves with the included content. Blogs help build the image of an industry expert by commenting on current events related to your business, publishing articles expanding the knowledge of visitors or publishing research reports related to the offer of the company (Małecki, 2008). Due to the aforementioned increased tendency of women to blogging, this way of communication needs to be promoted in the context of the development of women's enterprises.

\section{Social Media as a Tool for Brand Promotion}

The potential of social media was pretty quickly recognized by specialists in marketing and public relations in all sectors of the economy. Social media represent a free and efficient channel of communication with current and potential clients in a virtual environment where they look for information about products and companies. Monitoring social media channels enables companies to locate online statements from users commenting on their satisfaction with using the company's products and their perception of brand image. In addition, social media channels have heightened the importance of word-of-mouth marketing. Consumers using them in communication with their friends can be credible ambassadors of a particular brand and create its positive image (Pawlak, 2013).

In Poland, only $20 \%$ of companies are present in social media, while in the EU it is $42 \%$ (Śledziewska and Włoch, 2015). According to the DELab report, social networking is common to only $17 \%$ of companies, with multimedia services used by about $5 \%$. Blogs and microblogs are run by only about $3 \%$ (ibid., 2015). According to the E-commerce Report Poland in 2015 , one of the most popular ways of spending time online is the usage of Facebook. As many as $66 \%$ of Internet users answered that they used the Internet to use just Facebook. For comparison, Twitter is used by only $7 \%$ of Internet users, and the use of other social networking is declared by $32 \%$ (Raport E-commerce Polska 2015).

Almost every company focused on success has at least its profile on Facebook, Twitter or Youtube. According to Jahn, Kunz and Meyer, it has been a great way of changing the context of brand management in recent years and the relationship with the company's clients (Jahn, Kunz and Mejer, 2013). The essence is to move away from the perception of customers as passive recipients and provoke their involvement in social media to make them assume the role of co-founders and multipliers of information on the brand.

In social media, one can establish socalled company profiles allowing a continuous dialogue with customers or potential customers. This is particularly important in the context of creating a brand image in the eyes of the younger generation of customers at the age of 18-32. Messages published in social media are a good solution in the context of studies that show increasing reluctance to different advertising messages. Among the advantages of using this type of branding are: the speed of pushing the information, the possibility of an immediate response, low costs, the chance of a real dialogue with the targeted customer group, a large number of recipients). In the context of the above listed benefits and low financial outlay, it seems a good way to support the activities of SMEs, including those run by women (Moroz, 2013).

\section{Online Advertising}

The Internet has become a full-fledged advertising medium in recent years. Almost half of surveyed companies using the Internet for advertising purposes expected a revenue growth in 2015 (Kaczor, 2015). Companies today can advertise in many ways on the Internet.

Companies can promote their offers, e.g. through retargeting. Its essence is to send personalized recommendations for clients based on the previously viewed websites. Consumers who visited a company's online shop (and left it in the meantime) are shown ads on other websites that co- 
work with the online shop in a retargeting-advertising network. In defined areas of a new website, images of products are displayed to the Internet user who was formerly interested in the aforementioned e-shop. Researchers are trying to determine whether it is more effective than traditional, general brand advertising (Lambrecht and Tucker, 2013).

Małecki (2008) points out low-cost and effective forms of advertising:

- $\quad$ search engine advertising - keywords looked up by potential customers in exposed places of search engines and co-working websites. The advertiser will be charged only if the user clicks on a specific link.

- Banners of varying size, shape, and location on the web. The fee depends on the popularity of the site or the portal on which it has been placed.

- Newsletters - information sent by email to people who have declared interest in the products or services of the company.

The Internet has developed the forms of advertising that can be used by any entrepreneur. Promoting a business can start with small amounts and be done by the entrepreneur herself, an option available even for businesses with limited financial resources, including women running their own businesses.

\section{Electronic Banking}

E-finance is an important part of electronic business conducted via the Internet. This phenomenon includes: online banking, online brokerage, online lending, online credit information and e-micro credit initiatives (Riyadh, Bunker and Rabhi, 2010). Thus SME-entrepreneurs can increase efficiency, reduce transaction costs, broaden the range and enhance the quality of financial services. This is particularly important for small and medium businesses that often face limited access to formal financing sources because of the relatively high transaction costs in relation to small-scale credit (see: ibid.).

Cost reductions offered by electronic banking result from reducing the number of intermediaries and ultimately enable the delivery of more profitable financial services to entrepreneurs. Limited resources of small and medium-sized businesses make them potential recipients of e-financial services. The advantage, especially for female entrepreneurs, is also saving time, which is guaranteed by this form of business support.

\section{Internet as a Tool to Promote Women's Entrepreneurship in the Light of Private Research}

The research conducted by the authors shows that among the available forms of SME promotion and information support, the most valued sources of knowledge necessary to conduct business are professional portals and specialized websites. Below are the results of the research conducted in the period 2013-2014 on a group of Greater Poland women. 384 respondents were examined who determined the level of usefulness of professional portals and specialized websites in running their business (see. Table 1).

Table 1. Usefulness of professional portals and specialized websites in running own business (in \%)

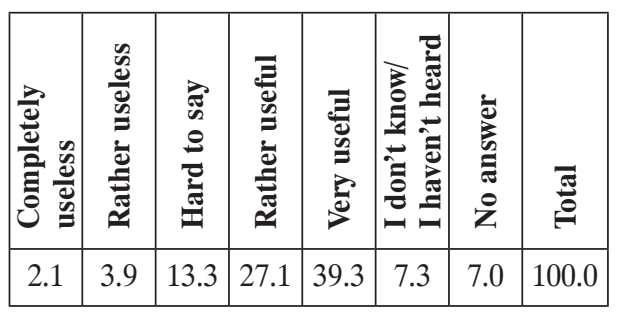

Source: private research.

In the next stage of the studies, the demographic characteristics of people who highly appreciate professional portals and specialized websites as a form of support were defined (see Table 1).

We used quota sampling of respondents who were female business owners from Greater Poland, and then conducted research using a proprietary survey. The following data were based on the analysis of the averages of the cross tables, which allowed the selection of the highest rates in the whole group of methods of promotion and information support. The figure below summarizes the characteristics of female entrepreneurs who evaluated professional portals and specialized web pages best (Figure 1). Average ratings given by them 
range from 4.3 to 4.56 on a scale of 1 to 5 , where 1 means useless support, and evaluation 5 - very useful support.

Figure 1. The characteristics of female entrepreneurs who evaluated professional portals and specialized web pages best

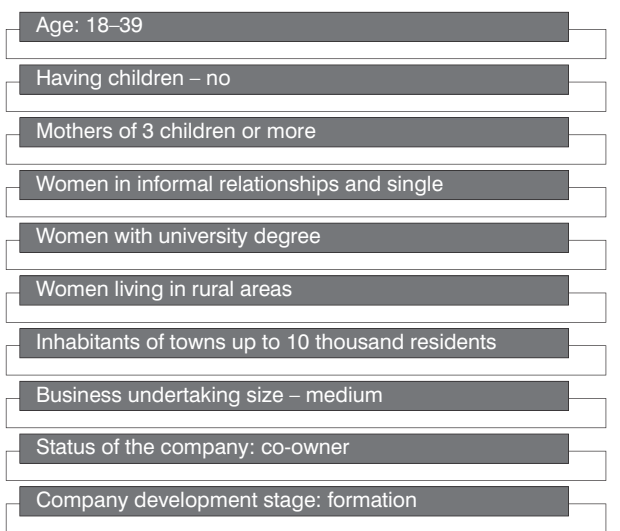

Source: private research.

The results of this study show that women-entrepreneurs highly appreciate the usefulness of the Internet. However, this is a medium the use of which varies depending on the demographic characteristics of entrepreneurs. What is interesting is that using it is especially popular among relatively young women (less than 40 years old), which on the one hand may be associated with high levels of technical expertise, and on the other can be motivated by the necessity to perform parental duties, which usually falls into this particular period in life.

In the context of the conducted research, quite surprising is a relatively low score of social networking as a means of supporting business activities. The following data were obtained (as described above) based on the analysis of the averages of the cross table. Figure 2 presents the characteristics of entrepreneurs who found this form of support most useless. Standard ratings assigned by users range from 3.25 to 3.48 .

The results presented above illustrate the situation of enterprises that evaluate the usefulness of social networking sites as low (Figure 2). These are companies run by older people, the so-called groups at risk of digital exclusion, and a low score is the result of the lack of awareness of the opportunities that come from the Internet use. In addition, a conclusion can be drawn about the relationship of the current downward trend of their companies (which have existed on the market for more than 10 years) with the difficulty in keeping up with the development of the global computer network. The results confirm the enormous importance of the Internet in promoting women's entrepreneurship.

Figure 2. The characteristics of female entrepreneurs who found social networking most useless

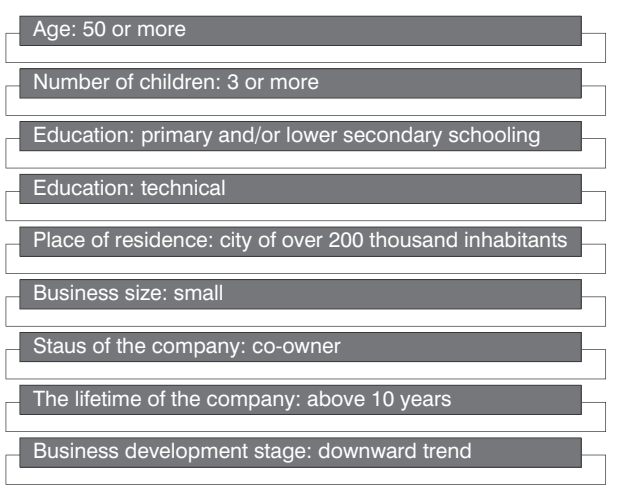

Source: private research.

\section{Conclusion}

Using the Internet is very popular both in the world and in Poland. Recently, visible changes have taken place in the way of using the network which is a common channel of exchange of goods and services. This makes the new medium an important tool which facilitates managing and developing your own business. It enables efficient financial service of the project, as well as obtaining the necessary information, establishing contacts or searching for employees.

The Internet is an important tool in the context of the activity of women-entrepreneurs due to the possibility of flexible work organization, which facilitates the reconciliation of the parental role and a professional activity. Hence, it is advisable to study the awareness, level of use and limitations on the use of various kinds of tools and web applications. This article is of a review and conceptual nature but also relies on the results of previous studies conducted by the authors. In the future, the authors plan to continue deepened empirical research in the described area. 


\section{Endnotes}

1 In comparative studies of European countries, it is estimated at $67.5 \%$, http://www.internetworldstats.com/stats4.htm, data as from November 2015.

2 An example might be www.siecprzedsiebior czychkobiet.pl, which promotes business networking: developing and nurturing contacts with other entrepreneurs, promoting knowledge sharing, providing help or recommendation of services.

\section{References}

Balcerzak-Paradowska, B., Bednarski, M., Głogosz, D., Kusztelak, P., Ruzik-Sierdzińska, A. and Mirosław, J. (2011). Przedsiębiorczość kobiet w Polsce. Warszawa: PARP.

Chodak, G. (2010). Internet jako dodatkowy kanał dystrybucji - efekt synergii czy kanibalizmu. Gospodarka Materiatowa i Logistyka, 62(9), 8-15.

Chodak, G. and Ropuszyńska-Surma, E. (2004) Możliwości oraz bariery wykorzystania internetu przez małe i średnie przedsiębiorstwa. Zeszyty Nau kowe Wyższej Szkoty Zarządzania „Edukacja” we Wroctawiu.

Fisher, H. (2003). Pierwsza pteć. Warszawa: Wyd. Jacek Santorski \& Co.

Internet World Stats. Usage and Population Statistics. Retrieved from: http://www.internetworldstats.com/ stats4.htm (18.06.2016).

Jahn, B., Kunz, W.H. and Meyer, A. (2013). The role of social media for luxury-brands - Motives for consumer engagement and opportunities for businesses. Retrieved from: http://papers.ssrn.com (15.07.2016).

Kaczor, D. (2015). Mate i średnie przedsiębiorstwa $w$ Internecie. Retrieved from: http://semahead.pl/ blog/male-i-srednie-przedsiebiorstwa-w-internecie. html (6.07.2016)

Komunikat z badań CBOS, Internauci 2015 (2015). No. 90/2015. Warszawa.

Kumar, V. and Dange, U. (2012). A study of factors affecting online buying behavior: A conceptual model. Retrieved from: http://papers.ssrn.com (01.08.2016).

Lambrecht, A. and Tucker, C.E. (2013). When does retargeting work? Information specificity in online advertising. Journal of Marketing Research, 50(5), 561-576.

Leicht, R. and Lauben-Ulbrich, M. (2005). Soloselbstandige Frauen in Deutschland: Entwicklung, wirtschaftliche Orientung und Ressourcen. Retrieved from: www.ifm.uni-mannheim.de/unter/fsb/nr3.pdf (12.07.2016).

Łuczka, T. (2013). Makro i mikroekonomiczne determinanty struktury kapitału $w$ matych $i$ średnich przedsiębiorstwach. Poznań: Wydawnictwo Politechniki Poznańskiej.
Małecki, B. (2008). Marketing i reklama $w$ Internecie. Warszawa: PARP.

Mail, R., Gołoś, A., Szczerbacz, K. and Walkiewicz, P. (2010). Strategiczne źródta informacji $w$ dziatalności przedsiębiorstw. Raport $z$ badania. Warszawa: PARP.

Martin, R.J. and Osberg, S. (2007). Social entrepreneurship: The case for a definition. Stanford Social Innovation Review, Spring.

Moroz, M. (2013). Efekty budowania wizerunku marki poprzez serwisy społecznościowe - badanie opinii internautów pokolenia y. Studia Ekonomiczne, 157, Wykorzystanie nowych mediów w public relations, 123-132. Uniwersytet Ekonomiczny w Katowicach.

PARP (2014). Global Entrepreneurship Monitor. Polska. Raport z badań 2013. Warszawa.

Pawlak, J. (2013). Promocja internetowa mikro i małego przedsiębiorstwa w portalu społecznościowym Facebook. Zeszyty Naukowe Uniwersytetu Szczecińskiego, 752, Ekonomiczne problemy ustug No. 102, 136-144. Szczecin.

Raport e-commerce Polska 2015 (2015). Retrieved from: www.gemius.pl (12.07.2016).

Rembiasz, M. (2014). Dojrzała przedsiębiorczość wybrane problemy. Zeszyty Naukowe Uniwersytetu Szczecińskiego, 799, Ekonomiczne problemy ustug No. 111, 165-174. Szczecin.

Rembiasz, M. (2016). Entrepreneurship of single mothers: Selected economic and social aspects. Zeszyty Naukowe Politechniki Poznańskiej. Organizacja i Zarządzanie, 68, 167-179.

Riyadh, A.N., Bunker, D. and Rabhi, F. (2010). Barriers to e-finance adoption in small and medium enterprises (SMEs) in Bangladesh. In: E-finance in SMEs. 5th Conference on Qualitative Research in IT, Brisbane.

Robb, A., Coleman, S. and Stangler, D. (2014). Source of economic hope: Women's entrepreneurship, Kansas City: Ewing Marion Kauffman Foundation. Siemieniak, P. and Łuczka, T. (2016). Przedsiębiorczość kobiet. Wybrane aspekty ekonomiczne $i$ psycho-kulturowe. Poznań: Wyd. Politechniki Poznańskiej.

Siemieniak, P. (2015). Wybrane problemy przedsiębiorczości kobiet w Wielkopolsce. Zeszyty Naukowe Uniwersytetu Szczecińskiego, 848, Ekonomiczne problemy ustug No. 116, 169-179. Szczecin.

Śledziewska, K. and Włoch, R. (2015). Kompetencje cyfrowe polskich matych $i$ średnich przedsiębiorstw. DELab report. Warszawa: DELab UW.

Śledziewska, K., Gabryelczyk, R. and Włoch, R. (2015). Go digital! Diagnoza luki w kompetencjach cyfrowych MSP. DELab working paper, No. 1.

Talar, S. and Kos-Łabędowicz, J. (2014). Internet $w$ dziatalności polskich przedsiębiorstw. Katowice: 
Wydawnictwo Uniwersytetu Ekonomicznego w Katowicach.

Wasilczuk, J. (2014). Przedsiębiorcy 55+, czy wiek ma znaczenie? Zeszyty Naukowe Uniwersytetu Szczecińskiego, 799, Ekonomiczne problemy ustug No. 111, 196-206. Szczecin.

Wojciechowska, Z. (2012). Macierzyństwo - czynnik wykluczenia na współczesnym rynku pracy czy szansa dla nowych rozwiązań w kobiecej karierze? Edukacja Dorostych, 1, 75-88.
Zabierowski, P., Węcławska, D., Tarnawa, A. Zadura-Lichota, P. and Bratnicki, M. (2012). Raport z badania Global Entrepreneurship Monitor - Polska 2011. Warszawa: Wydawnictwo Naukowe Instytutu Technologii Eksploatacji - PIB.

http://www.promocjakobiet.pl (3.06.2016)

http://fundacjamama.pl (1.03.2016)

http://miastomamy.wix.com/fundacjag10\#!aktu alnoci/c11hh (2.07.2016) 